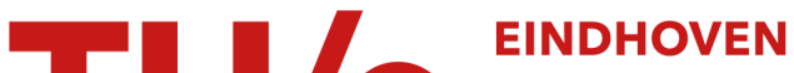 UNIVERSITY OF TECHNOLOGY
}

\section{Experimental study of the temporal behaviour of a mode group diversity multiplexing link}

\section{Citation for published version (APA):}

Tsekrekos, C., Boer, de, M., Martinez, A., Willems, F. M. J., \& Koonen, A. M. J. (2006). Experimental study of the temporal behaviour of a mode group diversity multiplexing link. In Proceedings of the Conference on Lasers and Electro-Optics (CLEO/QELS 2006), 21 - 26 May, 2006, Long Beach, California, USA (pp. CMJ6-2). Institute of Electrical and Electronics Engineers. https://doi.org/10.1109/CLEO.2006.4627780

DOI:

10.1109/CLEO.2006.4627780

Document status and date:

Published: 01/01/2006

\section{Document Version:}

Accepted manuscript including changes made at the peer-review stage

\section{Please check the document version of this publication:}

- A submitted manuscript is the version of the article upon submission and before peer-review. There can be important differences between the submitted version and the official published version of record. People interested in the research are advised to contact the author for the final version of the publication, or visit the $\mathrm{DOI}$ to the publisher's website.

- The final author version and the galley proof are versions of the publication after peer review.

- The final published version features the final layout of the paper including the volume, issue and page numbers.

Link to publication

\section{General rights}

Copyright and moral rights for the publications made accessible in the public portal are retained by the authors and/or other copyright owners and it is a condition of accessing publications that users recognise and abide by the legal requirements associated with these rights.

- Users may download and print one copy of any publication from the public portal for the purpose of private study or research.

- You may not further distribute the material or use it for any profit-making activity or commercial gain

- You may freely distribute the URL identifying the publication in the public portal.

If the publication is distributed under the terms of Article $25 \mathrm{fa}$ of the Dutch Copyright Act, indicated by the "Taverne" license above, please follow below link for the End User Agreement:

www.tue.nl/taverne

Take down policy

If you believe that this document breaches copyright please contact us at:

openaccess@tue.nl

providing details and we will investigate your claim. 


\title{
Experimental Study of the Temporal Behaviour of a Mode Group Diversity Multiplexing Link
}

\author{
C. P. Tsekrekos, M. de Boer, A. Martinez, F. M. J. Willems, A. M. J. Koonen \\ Eindhoven University of Technology, Department of Electrical Engineering, P.O. Box 513, 5600 MB Eindhoven, The Netherlands \\ E-mail: c.tsekrekos@tue.nl
}

\begin{abstract}
This paper reports an experimental investigation on the temporal variations of the transmission matrix of a 2-input 2-output mode group diversity multiplexing MMF link; such a link is shown to be very stable. (C)2006 Optical Society of America

OCIS codes: (060.4510) Optical communications; (060.4230) Multiplexing
\end{abstract}

\section{Introduction}

Mode group diversity multiplexing (MGDM) has been proposed for the transparent transmission of several signals over short reach multimode fibre (MMF) links, such as in future in-house networks [1]. MGDM is an optical multiple-input multiple-output (MIMO) technique, in which $N$ sources excite each a different group of modes and $M(M \geq N)$ spatially selective detectors respond to a different part of the near field pattern (NFP) at the MMF output. The $M$ received signals are related to the $N$ transmitted ones via an $M x N$ transmission matrix $\mathbf{H}$, whose elements $h_{\mathrm{ij}}$ are the impulse responses of the $i^{\text {th }}$ output to the $j^{\text {th }}$ input. The $N$ input signals are recovered by the electrical processing of the $M$ output ones, provided that matrix $\mathbf{H}$ is known. In the cases where the effect of dispersion can be neglected, real-valued $h_{\mathrm{ij}}$ coefficients can be used to fully recover the input signals; otherwise further electrical compensation is required. One way to estimate the real-valued $h_{\mathrm{ij}}$ is by assigning an out-of-band (with respect to the bandwidth of the information-bearing signals) sinusoidal pilot tone at each channel and measure the power level of every pilot tone at each detector.

In this paper we present measurements of real-valued transmission matrix elements $h_{\mathrm{ij}}$ of a $2 \mathrm{x} 2 \mathrm{MGDM}$ link over a time period of 12 hours, using sinusoidal pilot tones. We used a $10 \mathrm{~m}$ long 185/250 $\mu \mathrm{m}$ silica graded index (GI) MMF and a $2 \mathrm{~km}$ long 148/200 $\mu \mathrm{m}$ silica GI-MMF, in order to investigate the system response when strong speckles are observed at the NFP as well as when non-negligible mode mixing takes place in the MMF.

\section{Experimental results}

Fig. 1 shows the 2x2 MGDM experimental set-up. At the transmitting side a fibre concentrator (FC) was used to excite simultaneously two different groups of modes. The FC transforms 32 waveguides (with a single mode cut off at $\sim 1200 \mathrm{~nm}$ ) from the standard pitch of $125 \mu \mathrm{m}$ to $30 \mu \mathrm{m}$ (fig. 2a). Two uncooled lasers of $635 \mathrm{~nm}$ were connected to two subsequent ports of the FC, allowing light to be launched at $0 \mu \mathrm{m}$ (transmitter 1, lower order modes) and 30 $\mu \mathrm{m}$ (transmitter 2, higher order modes) radial offset from the MMF axis. The receiver consisted of an optoelectronic IC (PDIC) which contains an array of 11 photo-detectors and pre-amplifiers (fig. 2b). The PDIC was originally designed for optical storage systems and has highest responsivity at visible light. Two PDIC segments were used as shown in fig. 3. Taking into account the dimensions of the PDIC photo-detectors and the core diameters of the two MMFs, a lens was used to magnify the NFP at the MMF output by a factor of 2 and project it on the PDIC.

To measure the transmission coefficients $h_{\mathrm{ij}}$, the laser that consists transmitter 1 (2) and excites the lower (higher) order modes channel was intensity modulated with a pilot tone of 7 (8) MHz. The bias point of the lasers and the modulation depth were chosen so as to yield the most linear output. The power level at each pilot tone was estimated by the FFT of the two PDIC outputs, with an integration period of $82 \mu$ sec for each measurement.

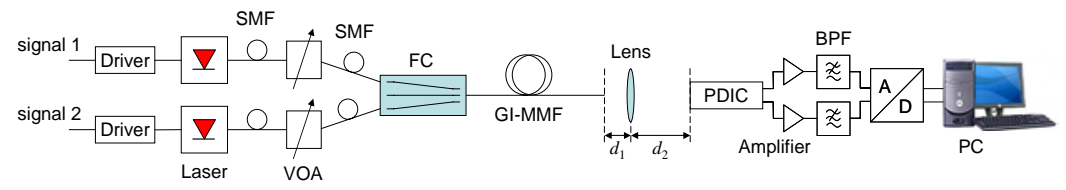

Fig. 1. MGDM experimental set-up.

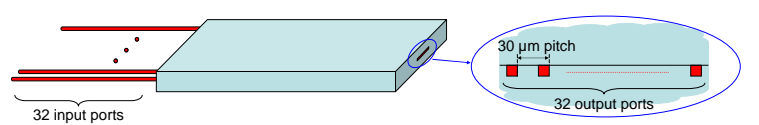

(a)

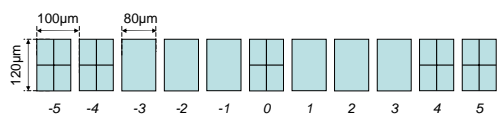

(b)

Fig. 2. (a) Fibre concentrator. (b) PDIC photo-detectors. 


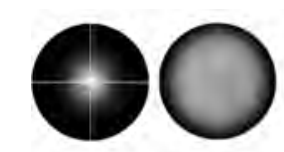

(a)

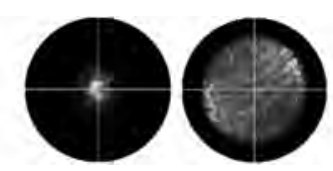

(b)

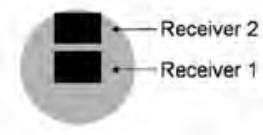

(c)

Fig. 3. NFP of the lower (left) and higher (right) order modes channel at the output of the (a) $2 \mathrm{~km}$ and (b) $10 \mathrm{~m}$ long MMF. (c) Receiving side of the set-up where gray colour indicates the magnified NFP of the higher order modes channel and black the PDIC segments.
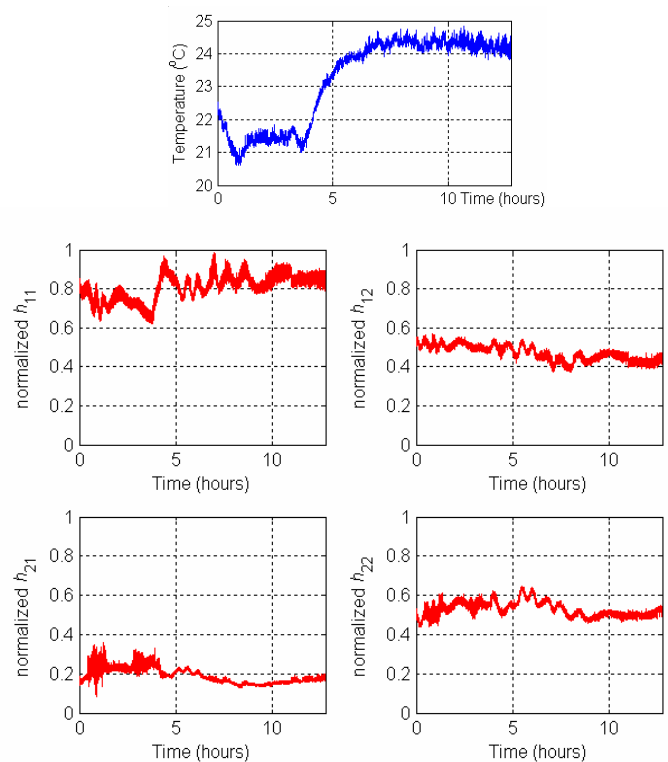

(a)
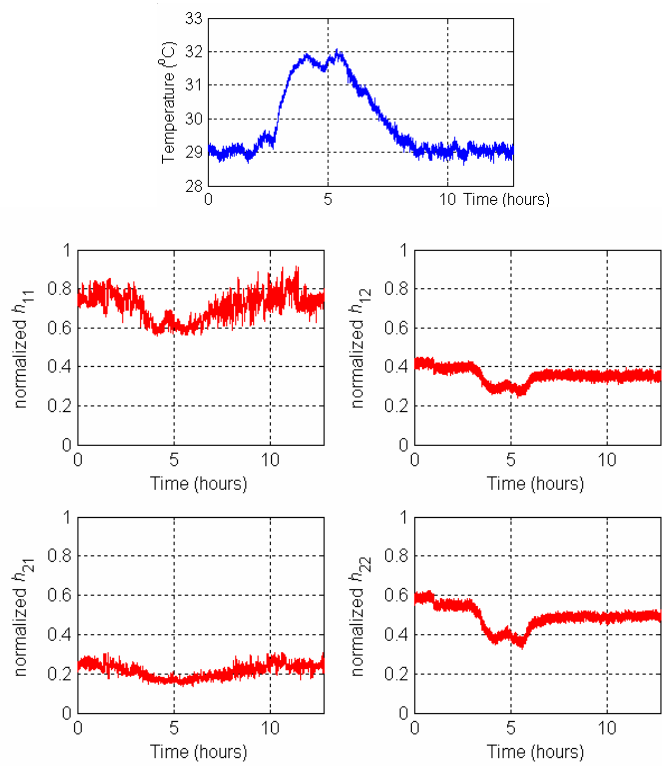

(b)

Fig. 4. Temporal variations of the transmission matrix elements $h_{\mathrm{ij}}$ when the (a) $10 \mathrm{~m}$ MMF (b) the $2 \mathrm{~km}$ MMF is used, together with temperature measurements during the same period. The value of the $h_{\mathrm{ij}}$ is normalized to the average $h_{1 \mathrm{j}}+h_{2 \mathrm{j}}$.

Fig. 4 shows the measured $h_{\mathrm{ij}}$ coefficients over time duration of 12 hours, normalized to the average $h_{1 \mathrm{j}}+h_{2 \mathrm{j}}$. In all cases the value of the $h_{\mathrm{ij}}$ shows moderate temporal variations, allowing for a stable link. The observed variations occur because of changes in the mode spectrum of the excited groups of modes (channels) as well as variations in the output optical power of the lasers, which operated without any power feedback control loop. The modal spectrum changes due to effects such as temperature variations, mechanical disturbances and launch conditions variations taking into account that the FC waveguides are not single mode at $635 \mathrm{~nm}$. Reduced speckle contrast at the NFP makes the changes in the mode spectrum of the channels less visible at the receiver. From the spatial confinement of the NFP of the lower order modes channel (fig. 3), it seems that mode mixing is much stronger in the case of the $2 \mathrm{~km}$ MMF, as expected. Intra-group mode mixing averages the effect of modal spectrum variations. For these reasons the temporal variations of transmission coefficients in the case of the $2 \mathrm{~km}$ MMF are very smooth and clearly associated with the corresponding temperature changes (fig. 4).

In conclusion, we have shown that the temporal response of an MGDM link shows significant stability. Recently we have presented geometric considerations for an MGDM transceiver that yields a transmission matrix fairly independent on the fibre length for up to $1 \mathrm{~km}$ of standard silica graded-index MMF [2]. These results show that the MGDM technique can be a simple and stable way to multiplex transparent communication channels over short graded index MMF links.

\section{Acknowledgements}

The authors would like to thank Alexander van der Lee (Philips Research) for providing the PDIC. Funding from the Freeband Impulse programme of the Dutch Ministry of Economic Affairs is gratefully acknowledged.

\section{References}

[1] T. Koonen, H. van den Boom, I. T. Monroy, G. D. Khoe, "High Capacity Multi-Service In-House Networks using Mode Group Diversity Multiplexing,” Proc. of OFC 2004, Los Angeles, CA, February 2004, paper FG4.

[2] C. P. Tsekrekos, A. Martinez, F. M. Huijskens, A. M. J. Koonen, "Mode Group Diversity Multiplexing Transceiver Design for Graded-Index Multimode Fibres,” Proc. of ECOC 2005, Glasgow, UK, September 2005, paper We4.P.113. 